\title{
Peran Fibrinogen Serum sebagai Prediktor Perforasi pada Pasien Apendisitis Akut di RSUP Dr. Hasan Sadikin Bandung 2018
}

\author{
Joko Suprayitno $^{1}$, Reno Rudiman ${ }^{2}$, Tommy Ruchimat ${ }^{2}$ \\ ${ }^{1}$ Departemen Bedah, Universitas Padjadjaran, Bandung \\ ${ }^{2}$ Divisi Bedah Digestif, Departemen Bedah, Universitas Padjadjaran, Bandung
}

\begin{abstract}
Abstrak
Latar Belakang. Insidensi apendisitis perforasi di dunia mencapai 2 per 10.000 kelahiran hidup, untuk proporsi apendisitis perforasi sekitar 25\%. Kasus apendisitis di Indonesia berdasarkan data Kementerian Kesehatan RI pada tahun 2009 sebesar 596.132 kasus dengan persentase $3.36 \%$ dan meningkat pada tahun 2010 menjadi 621.435 kasus dengan persentase 3.53\%. Sedangkan insidensi di RS Hasan Sadikin pada tahun 2017 mencapai 83\% pasien yang datang dengan keluhan apendisitis telah mengalami perforasi. Pemeriksaan radiologik seperti computed tomography scan (CT), magnetic resonance imaging (MRI) ataupun ultrasonography (USG) memiliki sensitifitas dan spesifitas yang tinggi untuk mendiagnosis perforasi apendisitis, tetapi alat-alat ini tidak selalu tersedia di institusi-institusi kesehatan negara berkembang. Fibrinogen sebagai faktor koagulasi yang pertama kali ditemukan dalam beberapa penelitian berpotensi digunakan sebagai prediktor perforasi pada pasien apendisitis, pemeriksaan fibrinogen dapat dilakukan sewaktu-waktu, memberikan hasil yang lebih cepat dengan harga yang lebih murah dibandingkan dengan pemeriksaan penunjang lain.

Metode. Penelitian observasional analitik dengan pendekatan cross-sectional. Subjek pasien apendisitis periode 1 April 2018 - 31 Desember 2018 yang datang ke Installasi Gawat Darurat RSUP Dr. Hasan Sadikin Bandung dan bersedia mengikuti penelitian. Pasien yang didiagnosis kerja awal sebagai apendisitis akut atau pasien dengan appendisits perforasi dengan gejala peritonitis lokal atau peritonitis difus setelah dilakukan pemeriksaan klinis dan laboratorium. Pasien dilakukan pemeriksaan fibrinogen serum preoperatif, lalu dilakukan operasi dan dicatat
\end{abstract}




\section{ARTIKEL PENELITIAN}

hasil temuan operasi yaitu yang mengalami perforasi dan yang tidak mengalami perforasi. Dilakukan pengelompokkan data setelah jumlah subyek penelitian terpenuhi.

Hasil. Sebanyak 40 pasien (25 laki-laki, 15 perempuan) terdiagnosis apendisitis berdasarkan Alvarado Score, yang terdiri dari 20 pasien apendisitis akut dan 20 pasien apendisitis perforasi. Akurasi kadar fibrinogen serum dalam memprediksi terjadinya perforasi sebesar $85 \%$. Nilai sensitivitas $90 \%$, nilai spesifisitas $80 \%$. Berdasarkan analisis kurva ROC diperoleh nilai Area Under Curve (AUC) sebesar 0,865 ( $\mathrm{p}=0,001)$. Menunjukkan bahwa kadar fibrinogen serum memiliki kemampuan diskriminasi yang tinggi dalam memprediksi terjadinya perforasi pada pasien apendisitis.

Kesimpulan. Kadar fibrinogen serum yang meningkat dapat digunakan sebagai prediktor terjadinya perforasi pada pasien apendisitis.

Kata kunci. Apendisitis perforasi, fibrinogen, prediktor

(ISSN 2723-7494 J Bedah Indonesia. 2020;48:3-14)

Korespondensi penulis:

Joko Suprayitno

Departemen Bedah, Universitas Padjadjaran, Bandung

Jalan Pasteur no. 38, Pasteur, Sukajadi, Bandung

Email : joesyazka@gmail.com 


\section{Latar Belakang}

Menurut Greg J. Beilman, insidensi apendisitis diperkirakan 100 per 100.000 kelahiran hidup dengan populasi $8,6 \%$ terjadi pada pria dan $6,7 \%$ pada wanita serta insidensi tertinggi terjadi pada usia dekade ke dua dan ketiga. Telah diketahui bahwa keterlambatan datang ke pusat pelayanan kesehatan merupakan penyebab tersering terjadinya apendisitis perforasi. Insidensi apendisitis perforasi di dunia mencapai 2 per 10.000 kelahiran hidup, untuk proporsi appendisistis perforasi sekitar $25 \%$. Kasus apendisitis di Indonesia berdasarkan data Kementerian Kesehatan RI pada tahun 2009 sebesar 596.132 kasus dengan persentase $3.36 \%$ dan meningkat pada tahun 2010 menjadi 621.435 kasus dengan persentase $3.53 \%$. Apendisitis merupakan penyakit tidak menular tertinggi kedua di Indonesia pada rawat inap di rumah sakit pada tahun 2009 dan 2010. Sedangkan Insidensi di RS Hasan Sadikin pada tahun 2017 cukup tinggi yaitu sekitar 83\% pasien yang datang dengan keluhan apendisitis telah mengalami perforasi. Sementara itu sampai saat ini tidak ada pemeriksaan yang akurat yang dapat menunjukkan kapan apendik tersebut telah mengalami perforasi. Etiologi dan patogenesis apendisitis belum sepenuhnya dimengerti. ${ }^{1,2}$ Obstruksi lumen yang disebabkan karena fekalit dan hipertropi jaringan limfoid diduga merupakan faktor etiologi utama pada pasien apendisitis dan frekuensi obstruksi meningkat dengan beratnya proses inflamasi. Fekalit dan Kalkuli ditemukan pada $40 \%$ kasus apendisitis akut, $65 \%$ pada kasus gangren apendik, dan hampir $90 \%$ pada kasus apendisitis dengan perforasi. ${ }^{3}$

Perforasi apendiks paling banyak terjadi di distal dari letak obstruksinya pada sepanjang tepi antemesenterik. Adanya perforasi harus dicurigai bila pasien mengalami demam dengan suhu $>39^{\circ} \mathrm{C}$ dan nilai lekosit > 18.000/mm3. Pada kebanyakan kasus, apendik yang telah mengalami perforasi menunjukkan tandatanda peritonitis lokal. ${ }^{1}$

Anamnesis dan pemeriksaan fisik yang pada kasus apendisitis diyakini sama akuratnya dengan modalitas pemeriksaan laboratorium lainnya untuk mendiagnosis apendisitis dan sering pasien perforasi apendisitis didiagnosis sewaktu pembedahan. Suatu penelitian yang dilakukan oleh Franz, dkk, menunjukkan bahwa angka kesalahan diagnosis apendisitis yang telah mengalami perforasi pada usia tua cukup tinggi yaitu mencapai angka $50 \% .^{4}$ 


\section{ARTIKEL PENELITIAN}

Pemeriksaan radiologik seperti computed tomography scan (CT), magnetic resonance imaging (MRI) ataupun ultrasonography (USG) memiliki sensitifitas dan spesifitas yang tinggi untuk mendiagnosis dan mengonfirmasi perforasi apendisitis, tetapi alat-alat radiologi ini tidak selalu tersedia di institusi-institusi kesehatan negara berkembang atau pada unit gawat darurat di rumah sakit negara berkembang sehingga kita hanya dapat mengandalkan pemeriksaan klinis dan hasil laboratorium untuk mendiagnosis suatu kasus yang dicurigai sebagai apendisitis atau kegawatan lain pada daerah abdomen. ${ }^{1,3}$

Pemeriksaan kadar leukosit dan $C$ reactive protein (CRP) paling sering dilakukan untuk menunjang diagnosis apendisitis khususnya peningkatan konsentrasi $\mathrm{C}$-reactive protein (CRP) merupakan indikator kuat terjadinya apendisitis terutama apendisitis komplikata. ${ }^{1}$ Pada suatu penelitian tahun 2015 menyatakan bahwa pemeriksaan Creactive protein $(C R P)$ dan White Blood cell (WBC) tidak berpengaruh dalam membuat suatu keputusan pada pasien apendisitis. ${ }^{4}$ Ada beberapa cara diagnostik dengan sistem skoring seperti Alvarado score, Tzanakis score atau Appendicitis
Inflammatory Response (AIR). Semua tipe sistem skoring tersebut terbukti sangat berguna dalam memprediksi apendisitis akut pada pasien dengan keluhan nyeri perut kanan bawah, namun masih belum mampu mengevaluasi adanya risiko apendisitis perforasi. ${ }^{1,3}$

Fibrinogen sebagai faktor koagulasi yang pertama kali ditemukan dalam beberapa penelitian berpotensi digunakan sebagai prediktor perforasi pada pasien apendisitis, pemeriksaan fibrinogen dapat dilakukan sewaktu-waktu, memberikan hasil yang lebih cepat dengan harga yang lebih murah dibandingkan dengan pemeriksaan penunjang lain, di RS Hasan Sadikin pemeriksaan fibrinogen serum berkisar Rp.118.000 dibandingkan dengan pemeriksaan penunjang lain seperti Computed Tomography scan (CT) dengan harga Rp.1.300.000 atau Ultrasonography (USG) dengan harga Rp. 350.000.

Menurut Li J dkk, pada penelitiannya menyatakan bahwa terjadi perubahan faktor koagulasi preoperatif pada pasien dengan apendisitis akut dimana endotoksin yang dihasilkan oleh bakteri akan menginduksi aktivasi jalur koagulasi ekstrinsik, dan pada akhirnya akan meningkatkan kadar fibrinogen serum yang terjadi pada pasien dengan apendisitis akut, 
pada penelitian ini terjadi peningkatan nilai fibrinogen serum $413 \pm 136 \mathrm{mg} / \mathrm{dL}$ pada apendisitis akut, $570 \pm 154 \mathrm{mg} / \mathrm{dL}$ pada apendisitis perforasi, $550 \pm 154 \mathrm{mg} / \mathrm{dL}$ pada abses periapendik sehingga dari penelitian ini dapat diambil kesimpulan bahwa fibrinogen berguna sebagai indikator potensial terjadinya appendistis komplikata lebih baik dibandingkan dengan faktor koagulasi lain seperti Protrombine Time (PT), Thrombine time (TT) dan lekosit. ${ }^{5}$

Pada penelitian lain, Feng S. dkk tentang fibrinogen sebagai suatu prediktor perforasi pada pasien apendisitis anak di Cina tahun 2014, penelitian ini dilakukan pemeriksaan serum fibrinogen preoperatif dan mendapatkan nilai sensitivitas $74 \%$, spesifitas $82 \%$ dan PPV $72 \%$, hal ini memberikan kesimpulan penelitian bahwa pasien anak dengan klinis apendisitis disertai dengan peningkatan kadar fibrinogen beresiko tinggi untuk terjadinya perforasi dibandingkan dengan pasien anak dengan klinis appedisitis yang mempunyai nilai fibrinogen yang normal ${ }^{6}$

Berdasarkan hasil jurnal-jurnal tersebut diatas peneliti tertarik untuk melakukan suatu penelitian untuk melihat bagaimana perbandingan efektifitas pemeriksaan kadar fibrinogen serum untuk memprediksi terjadinya perforasi pada pasien apendisitis di RSUP Dr. Hasan Sadikin Bandung 2018.

\section{Metode}

Penelitian ini menggunakan desain observasional analitik dengan pendekatan cross-sectional atau potong lintang yaitu suatu penelitian yang mempelajari peranan peningkatan kadar serum fibrinogen dalam memprediksi terjadinya perforasi pada kasus apendisitis.

Subjek adalah pasien penderita apendisitis periode 1 April 2018 - 31 Desember 2018 yang datang ke Instalasi Gawat Darurat RSUP Dr. Hasan Sadikin Bandung dan bersedia mengikuti penelitian Kriteria inklusi meliputi :

1. Pasien apendisitis akut atau apendisitis perforasi berusia lebih 18 tahun yang didiagnosis dengan Alvarado Score.

2. Pasien apendisitis dengan gejala peritonitis lokal atau difus yang datang ke UGD Bedah RS Hasan Sadikin.

Kriteria ekslusi meliputi :

1. Penyakit lain yang mempengaruhi kadar serum fibrinogen seperti penyakit yang berhubungan dengan gangguan Vaskular, pasien hamil, gangguan hati, nephrotic syndrome, Stroke, Spinal cord injury, Trauma otak, Multiple sklerosis, Alzehimer, Rheumatoid 
Arthiris, Kolitis, Fibrosis gijal, Duchenne muscular dystrophy. ${ }^{8}$

2. Pasien yang menolak untuk mengikuti penelitian ini

Pengambilan sampel ditentukan berdasarkan urutan datangnya pasien, yang dengan pemeriksaan klinis dan laboratorium didiagnosis kerja awal sebagai suatu apendisitis akut atau pasien dengan appendisits perforasi dengan gejala peritonitis lokal atau peritonitis difus, ke unit gawat darurat RSUP Dr. Hasan Sadikin Bandung.

Semua penderita yang memenuhi kriteria inklusi dilakukan pemeriksaan fibrinogen serum preoperatif, yaitu diambil sampel darah pasien $3-5 \mathrm{ml}$, masukkan darah ke dalam tabung tanpa antikoagulan, didiamkan selama 30 menit, centrifuge dengan menggunakan alat centrifuge selama 15 menit, diambil serum yang terbentuk lalu masukkan dalam alat spektrofotometri kemudian dibaca hasil yang keluar dari alat tersebut.

Pasien dilakukan operasi dan dicatat hasil temuan operasi yaitu yang mengalami perforasi dan yang tidak mengalami perforasi. Dilakukan pengelompokkan data setelah jumlah subyek penelitian terpenuhi.

\section{Hasil}

Sampel yang dilibatkan dalam penelitian ini adalah sebanyak 40 pasien (Tabel 1) yang didiagnosis mengalami apendisitis berdasarkan Alvarado Score, yang terdiri dari 20 pasien apendisitis akut dan 20 pasien apendisitis perforasi. Ratarata umur pasien adalah $31,0 \pm 13,1$ tahun dengan median 28 tahun dan rentang umur antara 18-76 tahun. Mayoritas pasien berjenis kelamin laki-laki (25 pasien atau $62,5 \%$ ).

Hasil analisis menunjukkan bahwa pasien apendisitis perforasi memiliki ratarata umur $(28,1 \pm 8,4$ tahun) yang lebih rendah daripada pasien apendisitis akut $(33,9 \pm 16,3$ tahun). Sedangkan untuk jenis kelamin, proporsi laki-laki dan perempuan pada pasien apendisitis perforasi (65\% lakilaki dan $35 \%$ perempuan) relatif hampir sama dengan pasien apendisitis akut $(60 \%$ laki-laki dan $40 \%$ perempuan).

Efektivitas pemeriksaan kadar fibrinogen serum untuk memprediksi terjadinya perforasi pada pasien apendisitis diuji berdasarkan klasifikasi standar kadar fibrinogen serum, yaitu $>400 \mathrm{mg} / \mathrm{dL}$ dan $\leq 400 \mathrm{mg} / \mathrm{dL}$. Berdasarkan penelitian empirik, kadar fibrinogen serum tertinggi pada kondisi normal adalah $400 \mathrm{mg} / \mathrm{dL}$. Dari total pasien apendisitis perforasi (20 
pasien), mayoritas pasien memiliki kadar fibrinogen serum yang tinggi, yaitu $>400$ $\mathrm{mg} / \mathrm{dL}$ (18 pasien atau 90,0\%). Sedangkan dari total pasien apendisitis akut (20 pasien), mayoritas pasien memiliki kadar fibrinogen serum yang rendah, yaitu $\leq 400$ $\mathrm{mg} / \mathrm{dL}$ (16 pasien atau $80,0 \%$ ). (Tabel 2)

Akurasi kadar fibrinogen serum dalam memprediksi terjadinya perforasi pada pasien apendisitis adalah sebesar $85 \%$. Sementara untuk nilai sensitivitas sebesar 90\%, lebih tinggi dari pada spesifisitasnya, yaitu sebesar 80\%. Tingginya tingkat sensitivitas dan spesifisitas kadar fibrinogen serum dalam memprediksi terjadinya perforasi menunjukkan bahwa kadar fibrinogen serum dapat digunakan sebagai alat diagnostik terjadinya perforasi pada pasien apendisitis.

Selain berdasarkan klasifikasi standar kadar fibrinogen serum, yaitu $>400$ $\mathrm{mg} / \mathrm{dL}$ dan $\leq 400 \mathrm{mg} / \mathrm{dL}$, efektivitas pemeriksaan kadar fibrinogen serum untuk memprediksi terjadinya perforasi pada pasien apendisitis juga diuji berdasarkan klasifikasi yang diperoleh dari hasil analisis kurva ROC (Receiver Operating Characteristic) (Gambar 1). Berdasarkan analisis kurva ROC diperoleh nilai Area Under Curve (AUC) sebesar 0,865 (p = 0,001). Nilai AUC ini menunjukkan bahwa kadar fibrinogen serum memiliki kemampuan diskriminasi yang tinggi dalam memprediksi terjadinya perforasi pada pasien apendisitis.

\section{Pembahasan}

Apendisitis akut dikaitkan dengan respon inflamasi sistemik yang sering menyebabkan aktivasi koagulasi. pada penelitian ini tingginya kadar fibrinogen serum dikaitkan sebagai penanda prediktif untuk terjadinya apendisitis perforasi.

Pemeriksaan fibrinogen lebih unggul dari pemeriksaan penunjang lainnya seperti CT scan dan USG, pemeriksaan fibrinogen dapat dilakukan sewaktu-waktu, memberikan hasil yang lebih cepat, dengan harga yang leibh murah yaitu Rp.118.000, dibandingkan USG apendik Rp. 350.000, dan CT scan Rp.1.300.000.

Dari hasil penelitian diatas dapat dilihat bahwa selama periode 1 April - 31 Desember 2018 terdapat 40 pasien yang didiagnosis mengalami apendisitis berdasarkan Alvarado Score (Tabel 1), yang terdiri dari 20 pasien apendisitis akut dan 20 pasien apendisitis perforasi. Ratarata umur pasien adalah $31,0 \pm 13,1$ tahun dengan median 28 tahun dan rentang umur antara 18-76 tahun. Mayoritas pasien berjenis kelamin laki-laki (25 pasien atau 


\section{ARTIKEL PENELITIAN}

$62,5 \%)$. Hal ini sesuai dengan literatur yang menyatakan bahwa insiden apendisitis paling banyak dijumpai pada dekade dua hingga dekade tiga. ${ }^{1}$

Dari total pasien apendisitis perforasi (20 pasien), mayoritas pasien memiliki kadar fibrinogen serum yang tinggi (Tabel 2), yaitu >400 mg/dL (18 pasien atau 90,0\%). Sedangkan dari total pasien apendisitis akut (20 pasien), mayoritas pasien memiliki kadar fibrinogen serum yang rendah, yaitu $\pm 400 \mathrm{mg} / \mathrm{dL}$ (16 pasien atau $80,0 \%)$.

Berdasarkan Tabel 2, diketahui $P$ value $(\mathrm{p}<0.001)$, maka dapat disimpulkan bahwa terdapat hubungan yang sangat signifikan antara peningkatan fibrinogen serum dengan apendisitis perforasi. Dari hasil penelitian juga didapatkan sensitivitas dan spesifitas yang tinggi dari perubahan kadar fibrinogen serum yaitu sebesar $90 \%$ dan $85 \%$. Tingginya tingkat sensitivitas dan spesifisitas kadar fibrinogen serum dalam memprediksi terjadinya perforasi menunjukkan bahwa kadar fibrinogen serum dapat digunakan sebagai alat diagnostik terjadinya perforasi pada pasien apendisitis.

Hal ini sesuai dengan penelitian Feng S, dkk pada penelitian yang dilakukan di Cina dengan sampel penelitian apendisitis pada anak yang menunjukan bahwa nilai spesifitas fibrinogen untuk diagnostik preoperatif apendisitis perforasi lebih tinggi $82 \%$ dibandingkan WBC (white blood cell) $25 \%$ dan CRP ( $C$ reactive protein) $34 \% .4$ Penelitian Li J dkk juga menyatakan bahwa untuk mendiagnosa apendisitis yang mengalami komplikasi, fibrinogen secara signifikan lebih baik dibandingkan dengan prothrombin time, thrombin time, leukosit dan neutrophil. ${ }^{5}$

Oleh karena itu berdasarkan kajian yang telah dilakukan peneliti, maka penilaian kadar fibrinogen serum preoperatif sangat berguna untuk membantu diagnostik.

\section{Kesimpulan}

Kadar fibrinogen serum yang meningkat dapat digunakan sebagai prediktor terjadinya perforasi pada pasien apendisitis.

\section{Daftar Pustaka}

1. Jeffrey BM, Berger DH. The Appendix. In: Brunicardi FC (ed) Schwartz's Principle of Surgery. 10th edition. McGraw-Hill; 2015. P. 1241-1062

2. Kementerian Kesehatan Republik Indonesia. Profil Kesehatan 
Indonesia. Jakarta: Departemen Kesehatan. 2009.

3. Zinner MJ, Scwhartz SI, Ellis H. Maingot's abdominal operations, $10^{\text {th }}$ edition vol 2. Toronto: McGraw-Hill Professional; 199

4. Franz MG, Norman J, Fabri PJ. Increased Morbidity of Appendicitis with Advancing Age. Am Surg 1995 Jan 61(1):40-4

5. Li J, Liu Y, Yin W et al. Alterations of the preoperative coagulation profile in patients with acute appendicitis. Clin. Chem. Lab. Med. 2011; 49: 1333-9

6. Feng $\mathrm{S}, \mathrm{Wu} \mathrm{P}$, Chen $\mathrm{X}$. Hyperfibrinogenemia in appendicitis: a new predictor of perforation in patients. Pediatr. Surg. Int. 2014; 30: 1143-7

7. Turner JR. Acute Appendicitis. In: Kumar V, Abbas AK, Fausto N, Robbins SL, Cotran RS (ed) Robbins and Cotran Pathologic Basis of Disease 7th edition. Elsevier Inc. Ch. 17:870-871;2005

8. Tennent GA, Brennan SO, Stangou AJ, O’Grady J, Hawkins PN (2007) Pepys MB Human Plasma Fibrinogen is synthesized in the liver. Blood 109(5): 1971-1974
9. Davalos D, Akassoglou K. Fibrinogen as a key regulator of inflamation in disease. Semin. Immunopathol. 2012; 34: 43-62

10. Schouten M, Wiersinga WJ, Levi M, van der Poll. Inflamation, endothelium and coagulation in sepsis.J. Leukoc. Biol. 2008; 83: $536-4$

11. Tind S, Lassen AT, ZimmermanNielsen E, Ovist N, C-Reactive protein and white blood cell count do not improve cinical decisionmaking in acute apendisitis. Dan Med J. 2015;62(12):516

12. Dawes T, Burrows C. Abdominal pain and jaundice: appendiceal perforation an important differential. Emerg Med Australas 2007;19:276- 78 .

13. Tzanakis $\mathrm{N}$, Efstathiou $\mathrm{S}$, Danulidis K et al. A New Approach to Accurate Diagnosis of Acute Appendicitis World J. Surg. 2005; 29, 1151-1156

14. Emily M, Zhen J, Fergus V et al. The equivocal appendix at CT: Prevalence in a control population. Emerg Radiol. 2010; 17:57-61

15. Burkitt HG, Quick CRG, Reed JB. Appendicitis. Dalam: Essential 


\section{ARTIKEL PENELITIAN}

Surgery Problems, Diagnosis, \& Management, $4^{\text {th }}$ edition. London:

Elsevier, 2007

16. Bailey H. Apendisitis Akut. Dalam: Dudley HAF, ed. Ilmu Bedah Gawat Darurat, edisi 11. Yogyakarta: Gadjah Mada University Press, 1992

17. Henry MC, Gollin G, Islam S et al. Matched analysis of nonoperative management vs immediate appendectomy for perforated appendicitis. J. Pediatr. Surg. 2007; 42: $19-23$
18. Walker A, Hatch Q, Drake T et al. Predictors of appendiceal perforation in an equal access system. J. Surg. Res. 2014; 190: 87-92

19. Sastroatmoro S, Ismael S. Dasardasar Metodologi Penelitian Klinis edisi ke-4. Jakarta: Sagung Seto, 2011.

20. Agresti, A. An Introduction to Categorical Data Analysis, 2nd Edition. John Wiley and Sons, Hoboken, New Jersey. 2007. 


\section{ARTIKEL PENELITIAN}

Tabel 1. Distribusi Umur dan Jenis Kelamin Pasien

\begin{tabular}{ccccccccc}
\hline & & & \multicolumn{5}{c}{ Usia } \\
$\begin{array}{c}\text { Jenis } \\
\text { Kelamin }\end{array}$ & $\mathrm{N}$ & $\%$ & Mean & SD & Median & Min & Max \\
\hline \hline Perempuan & 15 & 37.5 & & & & & \\
Laki-laki & 25 & 62.5 & 31.0 & 13.1 & 28 & 18 & 76 \\
Total & 40 & 100 & & & & & \\
\hline \hline
\end{tabular}

Tabel 2. Efektivitas Kadar Fibrinogen Serum sebagai Pediktor Perforasi pada Pasien Apendisitis

\begin{tabular}{|c|c|c|c|c|c|c|c|}
\hline & & $\begin{array}{c}\text { Apendisitis } \\
\text { perforasi }\end{array}$ & $\begin{array}{c}\text { Apendisitis } \\
\text { akut }\end{array}$ & Total & $P$ & $\mathrm{RR}$ & $95 \% \mathrm{CI}$ \\
\hline Kadar & $>400 \mathrm{mg} / \mathrm{dL}$ & 18 & 4 & 22 & $<0.001$ & 7.364 & 1.964 \\
\hline \multirow{5}{*}{$\begin{array}{l}\text { Fibrinogen } \\
\text { serum }\end{array}$} & & $90.0 \%$ & $20.0 \%$ & $55.0 \%$ & & & 27.60 \\
\hline & Perforasi) & & & & & & \\
\hline & $\leq 400 \mathrm{mg} / \mathrm{dL}$ & 2 & 16 & 18 & & & \\
\hline & (Apendisitis & $10.0 \%$ & $80.0 \%$ & $45.0 \%$ & & & \\
\hline & Akut) & & & & & & \\
\hline \multirow[t]{3}{*}{ Total } & & 20 & 20 & 40 & & & \\
\hline & & $100.0 \%$ & $100.0 \%$ & 100.0 & & & \\
\hline & & & & $\%$ & & & \\
\hline
\end{tabular}




\section{ARTIKEL PENELITIAN}

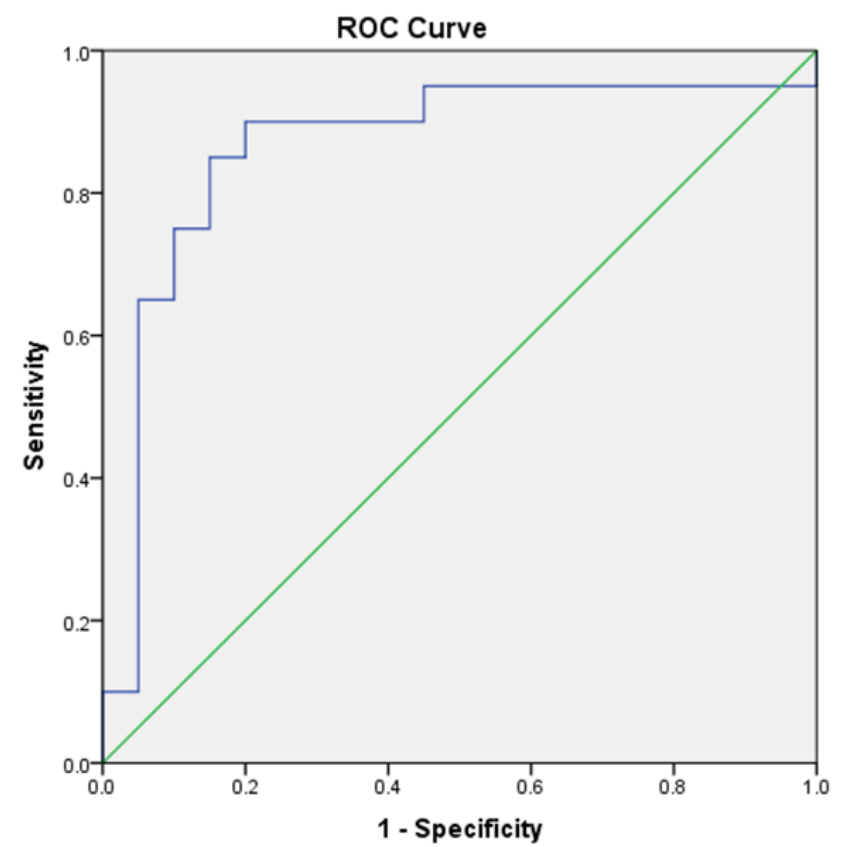

Gambar 1.Analisa kurva ROC untuk fibrinogen sebagai prediktor perforasi terhadap pasien apendsitis akut 